UDC 314.117.1(477.82)

Tetiana Serhiivna Pavlovska,

$\mathrm{PhD}$ (Geography), Associate Professor,

Department of Physical Geography, Faculty of Geography,

Lesya Ukrainka Eastern European National University,

9 Potapova Str., Lutsk, 43000, Ukraine,

e-mail: pavlovska2011@ gmail.com, https://orcid.org/0000-0003-4931-0803,

Taras Heorhiiovych Pohrebskyi,

$\mathrm{PhD}$ (Geography), Associate Professor,

Department of Economic and Social Geography, Faculty of Geography,

Lesya Ukrainka Eastern European National University,

e-mail: taraspogrebskyi@gmail.com, https://orcid.org/0000-0002-2290-134X;

Gennadii Serhiiovych Golub,

$\mathrm{PhD}$ (Geography), Associate Professor,

Department of Economic and Social Geography, Faculty of Geography,

Lesya Ukrainka Eastern European National University,

e-mail: golubgs111@ gmail.com, https://orcid.org/0000-0003-3548-6998;

Volodymyr Ivanovych Poruchynsky,

$\mathrm{PhD}$ (Geography), Associate Professor,

Department of Economic and Social Geography, Faculty of Geography,

Lesya Ukrainka Eastern European National University,

e-mail: poruchynsky@ gmail.com, https://orcid.org/0000-0002-4605-5424

\title{
URBAN POPULATION OF VOLN REGION: RESETTLEMENT AND DYNAMICS
}

Т. С. Павловська, Т. Г. Погребський, Г. С. Голуб, В. І. Поручинський. МІСЬКЕ НАСЕЛЕННЯ ВОЛИНСЬКОЇ ОБЛАСТI: РОЗСЕЛЕННЯ ТА ДИНАМІКА. У статті відображено результати аналізу розселення наявного міського населення у Волинській області станом на 01.01.2017 та динаміки його чисельності упродовж 01.01.2013-01.01.2017 рр. Для иього було охарактеризовано й закартографовано просторове поширення міських населених пунктів у межах області; з'ясовано рейтинг Волинської області серед інших регіонів Украӥни за часткою кількості міських населених пунктів $і$ часткою міських жителів; проаналізовано кількість наявного населення та його динаміку за вказаний п'ятирічний період в містах обласного підпорядкування та в інших міських населених пунктах краю; проаналізовано кількість наявного міського населення та його динаміку за вказаний час в адміністративних районах області; закартографовано й охарактеризовано просторовий розподіл частки міських жителів Волинської області в розрізі адміністративних районів; простежено динаміку урбанізаційних прочесів у Волинській області упродовж зазначеного часу. Дослідження здійснено із використанням статистичних даних Головного управління статистики у Волинській області та Державної служби статистики Украӥни. Застосовано такі методи досліджень, як порівняльно-географічний, математико-статистичний, геоінформаційного моделювання (з використанням MapInfo Professional 8.0 SCP). У процесі дослідження було відмічено стабілізацію урбанізаційних процесів у Волинській області в останні роки аналізованого періоду на рівні 52,3\%. При цьому в різних містах й адміністративних районах регіону простежується різновекторна динаміка кількості міських мешканиів. 3'ясовано, що на чисельність міського населення та рівень урбанізації Волинської області, крім природного відтворення населення і внутрішньорегіональної міграції, вагомий вплив мають міжрегіональні та міждержавні міграційні потоки. Стабільність показника урбанізації Волинської області на фоні скорочення чисельності міського населення деяких адміністративних районів та кількості мешканців більшості міст зумовлена зниженням числа сільських жителів регіону у зв'язку із природними й міграційними процесами.

Ключові слова: Волинська область, міграційний приріст, місто, міське населення, природний приріст, селище міського типу, урбанізаиія.

Т. С. Павловская, Т. Г. Погребский, Г. С. Голуб, В. И. Поручинский. ГОРОДСКОЕ НАСЕЛЕНИЕ ВОЛЫНСКОЙ ОБЛАСТИ: РАССЕЛЕНИЯ И ДИНАМИКА. В статье отражены результаты анализа расселения имеющегося городского населения в Волынской области состоянием на 01.01.2017 и динамики его численности в течение 01.01.2013-01.01.2017 г2. Для этого было охарактеризовано и закартографировано пространственное распространение городских населенных пунктов в пределах области; выяснено рейтинг Вольнсккой области среди других регионов Украины по доле количества городских населенных пунктов и доле городских жителей; проанализированы численность населения и его динамика за указанный пятилетний период в городах областного подчинения и в других городских населенных пунктах края; проанализированы количество имеющегося городского населения и его динамика за указанное время в административных районах области; закартографировано и охарактеризовано пространственное распределение доли городских жителей Вольнской области в разрезе административных районов; прослежена динамика урбанизационных процессов в Волынской области на протяжении указанного времени. Исследование осуществлено с использованием статистических данных Главного управления статистики в Волынской области и Государственной службы статистики Украины. Применены такие методы исследования, как сравнительно-географический, математико-статистический, геоинформационного моделирования (с использованием MapInfo Professional 8.0 SCP). В прочессе исследования было отмечено стабилизацию урбанизационных процессов в Волынской области в последние годы анализируемого периода на уровне 52,3\%. При этом в разных городах и административных районах региона прослеживается разновекторная динамика количества городских жителей. Выяснено, что на численность городского населения и уровень урбанизаџии Волынской области, кроме естественного воспроизводства населения и внутрирегиональной миграчии, существенное влияние имеют межрегиональные и межгосударственные миграционные (C) Pavlovska T. S., Pohrebskyi T. H., Golub G. S., Poruchynsky V. I. $\quad$ https://doi.org/10.26565/2410-7360-2019-50-11 
потоки. Стабильность показателя урбанизации Вольнской области на фоне сокращения численности городского населения некоторых административных районов и количества жителей большинства городов обусловлена снижением числа сельских жителей региона в связи с природными и миграционными процессами.

Ключевые слова: Вольнская область, миграционный прирост, город, городское население, естественный прирост, поселок городского типа, урбанизачия.

Introduction. Currently, the main form of people's resettlement is urban settlements. These social and spatial entities are the opportunity for the implementation of various types of activities and interests of the population, the expansion and intensification of interpersonal and group contacts [5; 14]. Along with the increase in the number of urban population, standard of living and the level of comfort are increasing; the modernization of the urbosphere (global urban system) becomes more dynamic, awareness of equal rights in society, the equal importance of respect for human rights, cooperation, and the common use of the environment become more dynamic. In addition to positive changes, urbanization is accompanied by tension in terms of basic natural resources use, problems in moral and ethical values, inconsistency in the life comfort demands with the rates of development of housing and communal services and the planning structure of cities, etc. Therefore, the study of the spatial and temporal evolution of the urban settlement systems is an important task on the regional, national and global levels.

Analysis of recent researches and publications. Urban settlements are the complex forms of resettlement and housekeeping management, consequently, the study of urbanization processes deals with the integration of different sciences.

The main features and current trends in urban processes are highlighted in works by North American and Western European urban geographers (urbanists). Paul Knox, Stephen Pinch, Linda McCarthy [26] explored the role of cities and urbanization in the post-industrial society thoroughly. Their works offer a consistent, comprehensive introduction to the urban geography, and highlight the historical and process-oriented approach in terms of North American focus. The above-mentioned approach provides a global context and comparative international perspective and illustrates all changes in employment in the European and North American cities, where the level of urbanization is one of the highest in the world. Benjamin Ofori-Amoah [20], in his works, examines a wide range of issues on the most common urban trends that geographers have drawn attention to while studying large cities. Michael J. Shapiro [25] explores the scientific theme that focuses on the relationship between city styles, especially when they express the micro-politics of urban life in various urban settlements, shifting the territorial focus of political research from the national to the global network of cities. Urban sociol- ogists Tim May and Beth Perry [24] have made a valuable contribution to an increasingly interdisciplinary study of complex urban problems. Meanwhile, they support concern regarding social disorders and fragmentation, conflicts, tension and cultural diversity of cities. They considered that urban sociology has once lost its leading role in urban research, and therefore it is important to raise the question of the future of geography and urban sociology.

Geographical, urban, economic, social, demographic, historical aspects of the development of urban socio-territorial formations, peculiarities of urbanization processes in Ukraine were studied by the following Ukrainian scientists: A. Buryachenko, O. Gladkyi, P. Gnativ, O. Gonchar, M. Grygorovych, I. Gukalova, O. Denysenko, A. Dotsenko, O. Dronova, T. Zastavetsky, F. Zastavnyi, V. Zinych , N.Illyashenko, Y. Kachan, G. Kovalenko, G. Komarnytska, V. Konstantynova, L. Koretsky, D. Kotenok, A. Koshil, B. Kubiyovych, D. Kuzmenko, V. Kucheravy, M.Melnyk, M. Mizhega, E. Mykhailova, S. Mokhnachuk, K. Nemets, L. Nemets, Ya. Oliynyk, N.Omelchenko, G. Onyshchuk, M. Palamarchuk, V.Peresiekin, Yu. Pitiurenko, B.Posatsky, I.Salii, K. Segida, A. Stepanenko, M. Tymchuk, O. G. Topchiev, A. Shabliy, L. Shevchuk, J. Shypulin, S. Shchegliuk, M. Fashchevsky, R. Yaremchuk and others $[1 ; 2 ; 4-6 ; 8 ; 10 ; 14 ; 17 ; 22 ; 23]$.

The analysis of the main demographic trends in the Ukrainian urban environment was reflected in the works of A. Buryachenko, I. Gudzelyak, A. Denysenko, N. Dnistryanska, M. Duran, K. Mezentsev, I. Mostova, Yu. Polohovska, I. Prybytkova, V. Sklyar, R. Chorny, V. Shchabelska, L. Fedoryshyna and others $[1 ; 4 ; 6 ; 14 ; 17]$. Also, the review of the urbanization processes in Ukraine during 1989-2013 regarding demographic indicators and regional economic trends is reflected in World Bank reports [18].

The issues of the urbanization processes development and urban population resettlement are relevant for Volyn region, so many scholars keep this question under review. Thus, V. Poruchynsky and M. Vlah revealed the historical and geographical analysis of the settlement system in Volyn region, the role of cities and their functions in the overall social and economic development of the region [3; 13]. Historical analysis of the urban population formation and the evaluation of modern urbanization processes in Volyn region are highlighted in the works of G. Holub and Ya. Oliynyk [12]. Y. Mol- 
chak, I. Androschuk, I. Myskovets [11] analyzed the level of urbanization in Volyn region. It was made from the perspective of administrative districts, taking into account the evolution in time. The location of the center of gravity of the urban population, the identification of trends in shifting the abovementioned center regarding urban population during 1979-2001, and the substantiation of the importance of Lutsk in the regional settlement system are disclosed by V. Lazhnik and S. Pugach [9]. O. Pryshchepa [15] devoted his monograph to the study of the social and national structure of the urban population in the Volyn province, the pace of urbanization processes in the above-mentioned territory in the second half of the $19^{\text {th }}$ and early $20^{\text {th }}$ centuries. V. Kychtyuk [7] analyzed the data on the cities and urban-type settlement of Volyn region, the number of their residents at the beginning of the $20^{\text {th }}$ century.

Despite the considerable number of works and researches on the above-mentioned topic, the problems of the geospatial organization of the urban population, the consequences of the trends of urbanization processes, the pace of transformation of the way and conditions of life in the urban environment require further research. It is caused by the fact that the indicators of urbanization are rather dynamic and characterized by high dependence on sociopolitical phenomena of the local, regional and global range. Despite the fact that there is no strong industrial development, Volyn region is interesting for the study of urbanization processes, because it has a border position and currently is the edge of migration activity strengthening. Regarding the abovementioned scientific papers on urban settlements and the urban population of Volyn region, only some of them reveal the indicators that are at the center of our research. In addition, the most recent data, analyzed in these publications, relate to the time periods of the last three censuses of the population (1979, 1989, 2001), beginning of 2010 and early 2014. Therefore, our research, which is based on the data of 01.01.2013-01.01.2017, is considered a logical step in the study of modern urbanization processes in Volyn region in order to find out the causes of trends in the dynamics of the urban population and justify the prospects for the development of demographic, social and economic situation of the region.

The aim and objectives of the article. The aim of the article is to analyze the distribution of the existing urban population in Volyn region as of 01.01.2017 and the dynamics of its number during the period of 01.01.2013-01.01.2017. In order to achieve it, the following objectives were set out: 1) to study the history of urbanization processes research in Ukraine and in Volyn region; 2) to characterize and map the spatial distribution of urban set- tlements in Volyn region; 3) to find out the rating of Volyn region among other regions of Ukraine by the share of urban settlements number and the proportion of urban residents; 4) to analyze the amount of the population and its dynamics in the cities of regional submission and in other urban settlements of the region; 5) to assess the size of the existing urban population and its dynamics at a specified time in the administrative districts of the region; 6) to map and review the spatial distribution of the urban residents share of Volyn region in the context of administrative districts; 7) to trace the dynamics of urbanization processes in Volyn region during the specified time and substantiate the trends revealed.

Materials and methods of research. The research is based on the data of the Main Department of Statistics in Volyn region and the State Statistics Service of Ukraine. The following research methods are used: comparative-geographical, mathematicalstatistical, method of geoinformation modeling (using MapInfo Professional 8.0 SCP).

Presentation of the main material and the substantiation of the obtained research results. As of 01.01.2017 in Volyn region there are 33 urban settlements: 11 cities (4 cities of regional subordination: Lutsk, Kovel, Novovolynsk, VolodymyrVolynskyi) and 22 urban-type settlements. Cherkasy, Transcarpathian, Mykolayiv, Rivne and Chernivtsi regions have fewer urban settlements than Volyn region.

In Volyn region, the largest number of urban settlements in the Horokhiv district (2 cities Horokhiv and Berestechko and 2 urban-type settlements - Senkevychivka and Marianivka). In addition to Horokhiv, two cities are also located in Volodymyr-Volynskyi district (Volodymyr-Volynskyi and Ustylug). Liubeshiv, Stara Vyzhivka, Shatsk and Lokachi districts have less number of urban settlements - only one urban-type settlement is represented here.

At the beginning of 2017, there were 544.6 thousand city residents in Volyn region. Almost 70\% of urban residents of the region are concentrated in the cities of regional subordination (217 thousand in Lutsk, 69.3 thousand in Kovel, 52.8 thousand in Novovolynsk, 39.1 thousand in VolodymyrVolynskyi). Among other cities in the region, the largest number of inhabitants is in Kivertsi (14.2 thousand), Rozhyshche (13.0 thousand), KaminKashyrskyi (12.5 thousand), and the smallest one is in Berestechko (1,7 thousand). The largest number of residents of urban-type settlements are situated in Manevychi (10,8 thousand) and Ratne (10,0 thousand), but the smaller - Senkevychivka (1,2 thousand). Among the administrative districts, the largest number of urban residents has Kivertsi (23.8 thousand), Rozhyshche and Horokhiv (almost 15.0 thou- 
sand) districts, and the smallest - Lokachi (3.9 thousand) and Volodymyr-Volynskyi (2, 2 thousand) districts (Fig. 1).

The share of urban population in the total population is considered to be the dominant official indicator of the level of urbanization. As of 01.01.2017, the share of urban population in Volyn region is $52.3 \%$, in Ukraine $-69.2 \%$. According to this indicator, Volyn region occupies the $18^{\text {th }}$ place among other Ukrainian regions. In Volyn region, the least urbanization level is typical for VolodymyrVolynskyi (8.7\%) and Lutsk (9.6\%) districts (Fig. 2 ), because within their boundaries there are cities of regional subordination, which are the centers of human resources attraction. The highest urbanization rate is typical for Rozhyshche (38.2\%), Kivertsi (37.3\%), Lyuboml (34.3\%), Turiisk (33.7\%), and Shatsk (31.6\%) districts. The attractiveness of urban settlements in these districts is primarily due to the increase in the supply of jobs in industrial, agroindustrial, agricultural, transport, and trade enterprises, compared to other Polissya districts. At the same time, rural residents who decide to move to urban settlements in order to find better jobs and a higher level of living choose the cities and villages of the above-mentioned districts, because they have advantages in cost of housing or its rent in compari- son with the largest industrial centers of the region. The significant concentration of population in Shatsk, not in the villages of Shatsk district, is associated with a small number of jobs for agricultural activities due to the high percentage of reserves, lakes, and forests of the region.

Regarding the dynamics of the urbanization level in the region, from the beginning of 2015 and before January 1, 2017, this figure remained unchanged at $52.3 \%$, while at the beginning of 2014 it was $52.2 \%$, and in $2013-52.1 \%$.

As for the dynamics of the existing urban population of Volyn region, then at the beginning of the five-year period under study (01.01.201301.01.2017), its gradual growth was observed. Recently, it has stopped (the urban population at the beginning of 2017 is 1 thousand people less than on January 1, 2016).

Fluctuations in the number of urban residents in the administrative districts of the region during the specified time are barely visible. The most noticeable increase in the number of urban residents can be traced in Kamin-Kashyrskyi, Lutsk, Liuboml, Manevychi, Ratne districts. As of the beginning of 2017, in all of these areas, except Liuboml, urban population is characterized by a positive natural increase. The increase in the number of residents of

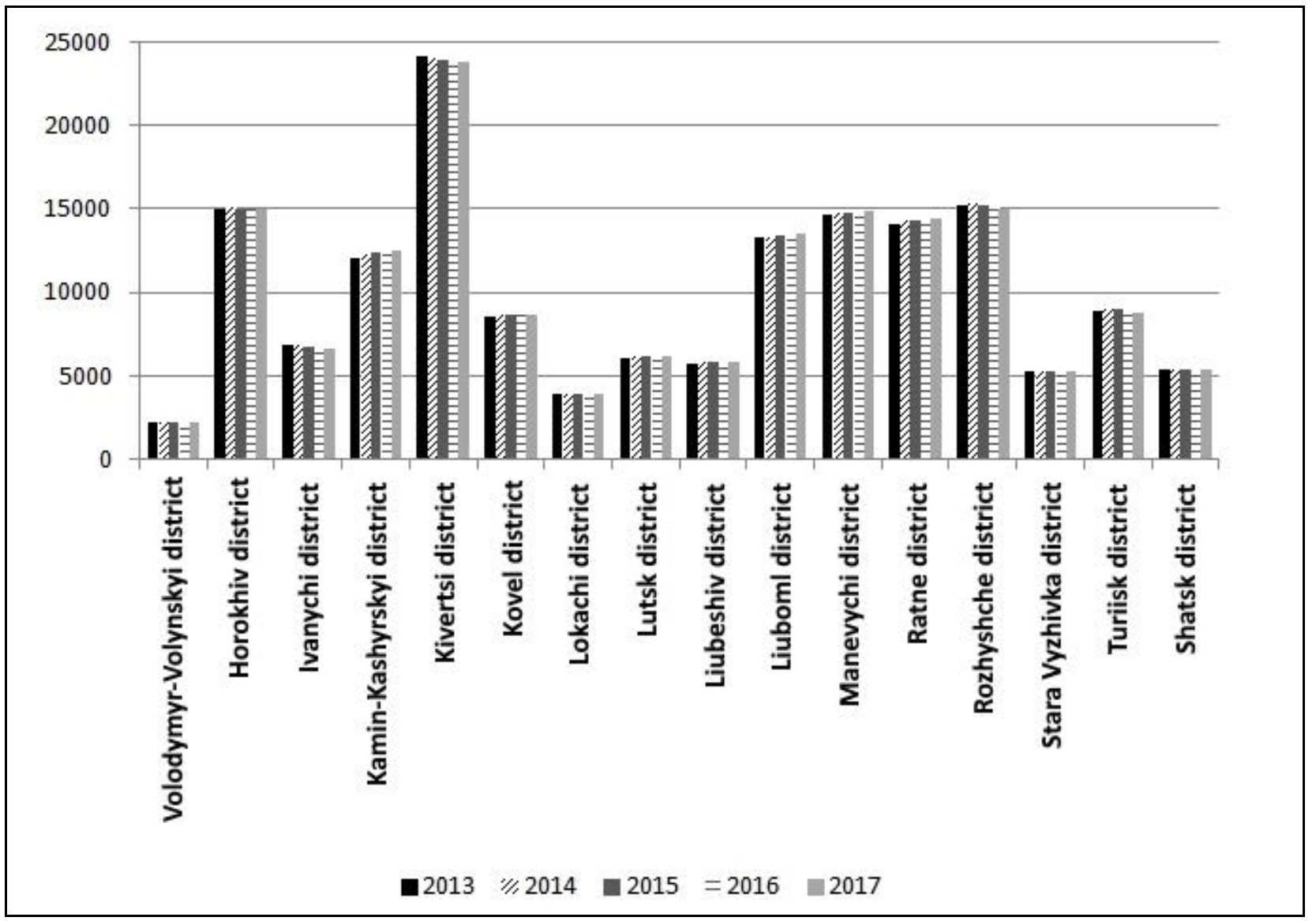

Fig. 1. Dynamics of the urban population number in administrative districts of Volyn region (according to [19]) 


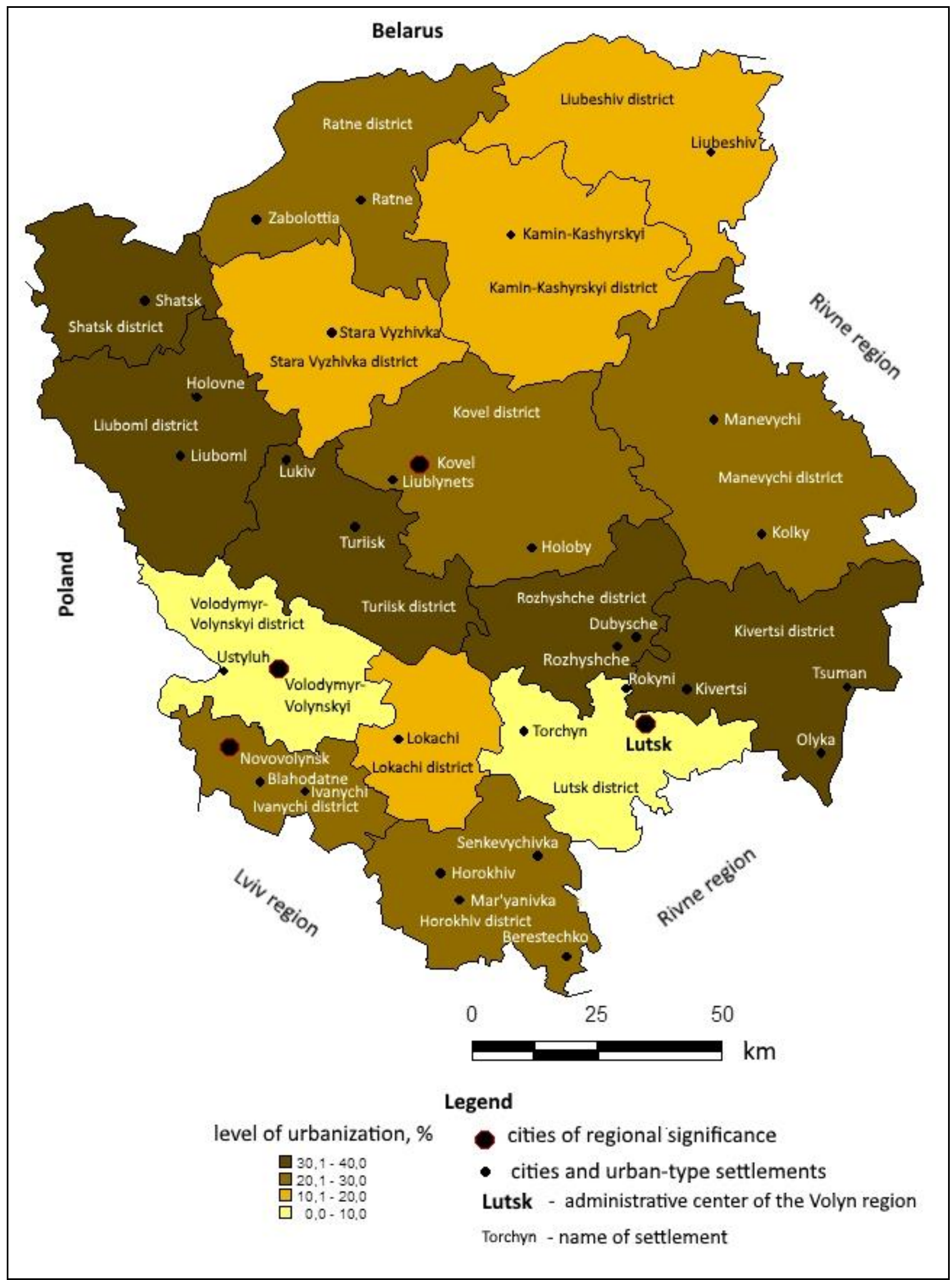

Fig. 2. Spatial differentiation of the urbanization level in Volyn region as of 01.01.2017 (drawn up by Pavlovska T. according to [16]) 
urban settlements in these areas is also marked by migration processes, especially in Liuboml district, where the indicators of migration increase offset the natural reduction of urban population. The gradual decrease of urban population occurs in Ivanychi, Kivertsi, Rozhyshche districts (see Fig. 2). In Kivertsi region, the positive values of the natural increase of urban population are inferior to the magnitude of migration outflow, and in Ivanychi and Rozhysche districts, in addition to migration processes, the negative values of natural growth are significantly affected by the reduction of the number of urban residents.

As for the cities of regional subordination, during the first four years of the studied period, the population of Lutsk and Volodymyr-Volynskyi slowly, but grew, and from 2016 began to decrease (Fig. $3)$. In Novovolynsk, the decline in the number of inhabitants has been traced since 2014. The dynamics of the number of residents in Kovel during January 1,2015 - January 1, 2017 has an oscillatory nature of changes. The population decline in these settlements is caused by the migration outflow (at the beginning of 2017, the migration balance in all these cities is negative, the largest migration outflow of the population can be traced in Lutsk and Novovolynsk). Regarding the natural movement of a population in recent years, only Lutsk and Kovel have a positive natural increase.

As for other cities in Volyn region, the gradual increase in the population during the specified time is traced in Kamin-Kashyrskyi (4\%) and Liuboml (by $2.2 \%$ ), and the decrease - in Kivertsi (by $2.6 \%$ ) and Rozhyshche (by 2.2\%). In other cities of district subordination, population changes are volatile without clearly expressed trends. The increase in the number of residents in Kamin-Kashyrskyi is explained by positive indicators of natural and mechanical movements of the population, and in Liuboml - the prevalence of positive values of migration increase over negative indicators of natural population growth (as of the beginning of 2017). Reducing population in Kivertsi and Rozhyshche is due to a significant migration outflow, as well as negative values of natural growth, in particular in 2016.

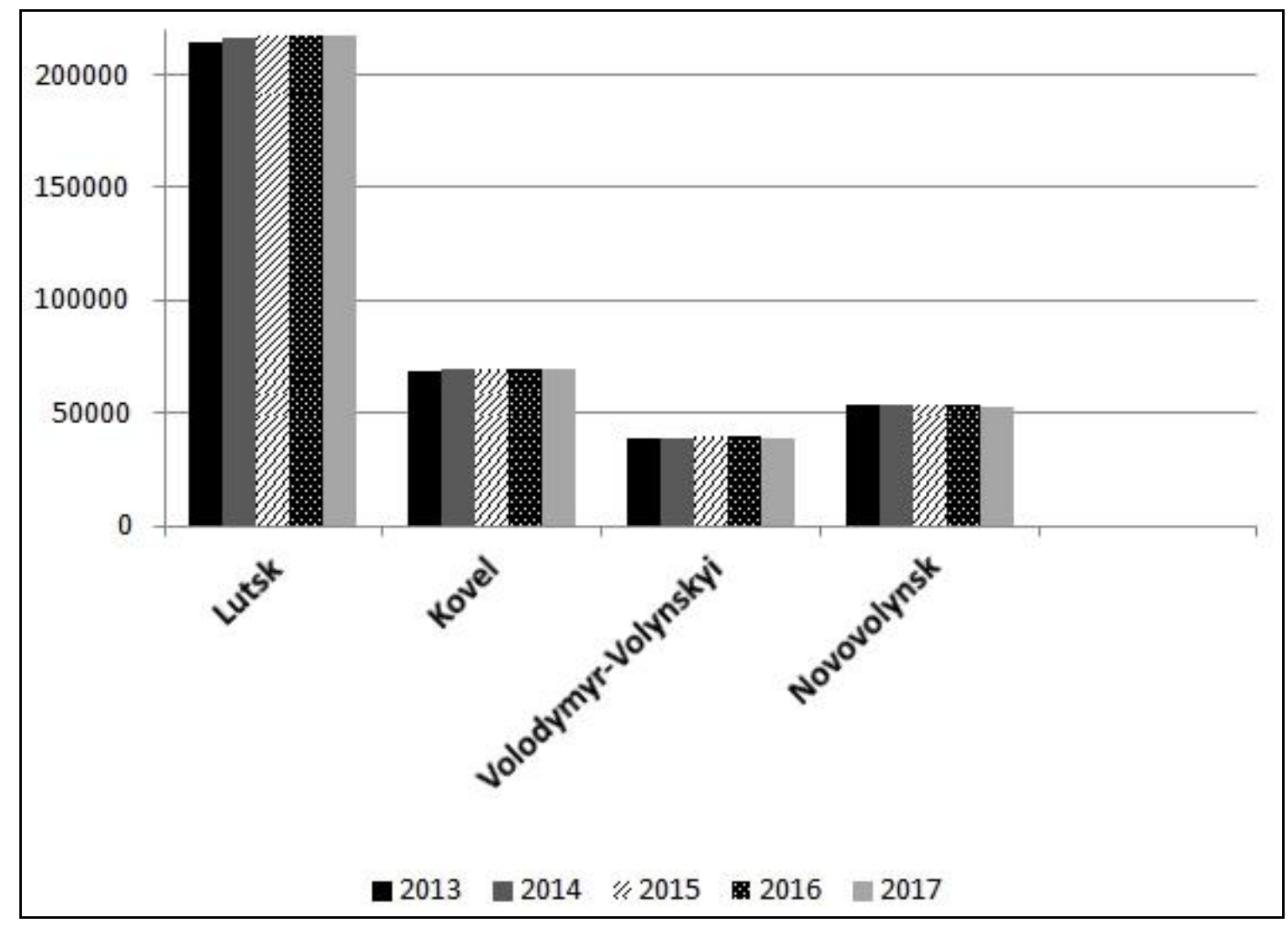

Fig. 3. Dynamics of the percentage of population in Volyn cities of regional subordination (according to [19])

Conclusions. In Volyn region, there are 33 urban settlements, that is $2.5 \%$ of all urban settlements in Ukraine. In the region there are 544.6 thousand urban residents, which make up $1.8 \%$ of all urban residents of the state. The main part of the urban population of the region $(70 \%)$ is concentrated in the cities of regional subordination (Lutsk, Kovel, Novovolynsk, Volodymyr-Volynskyi). More than 10 thousand people live in Kivertsi, Rozhyshche, Kamin-Kashyrskyi, Liuboml, and in the urban-type 
settlements Manevychi and Ratne. The level of urbanization in the region is much lower (52.3\%) than its republican value $(69.2 \%)$. The highest urbanization rate is typical for Rozhyshche (38.2\%), Kivertsi (37.3\%), Liuboml (34.3\%), Turiisk (33.7\%), and Shatsk (31.6\%) districts. Higher proportion of urban residents, compared to other Polissya districts, associated with the presence here of the three cities and seven towns, which attract a large number of visiting places of employment in industrial enterprises, transport and services, more developed infrastructure and, consequently, higher comfortable living. There are seven urban-type settlements that attract less people to stay there because of low level of economic and social development. These are Ratne, Liubeshiv, Stara Vyzhva, and Manevychi. The tendency of population to move to cities and towns is caused by reluctance of young people to work in rural areas, where they see few job prospects and personal development in connection with the crisis of social and economic nature that are inherent in most rural settlements not only in the region, but in whole Ukraine .

The low level of urbanization of VolodymyrVolynskyi, Lutsk and Kovel districts is due to the presence of cities of regional subordination, which are centers of attraction of human resources. In addition, the relatively low urbanization of forest-steppe districts of Volyn region is conditioned by a significant number of villages and residents in them due to the availability of opportunities for the effective application of agricultural labor through the proliferation of fertile soils.

During 01.01.2013-01.01.2017 there was a gradual increase in the number of urban residents during the first four years in Volyn region. At the beginning of 2017, this trend was reversed: the number of local people in the region became 1 thousand less compared to the beginning of 2016. Taking into consideration administrative regions, the most pronounced increase in urban population was seen in Kamin-Kashyrskyi, Lutsk, Liuboml, Manevychi, Ratne districts. At the beginning of 2017, in all of these areas, except Liuboml, the urban population is characterized by a positive natural increase. The increase in the number of residents of urban settlements in the above-mentioned areas is also marked by migration processes, especially in Liuboml district, where the indicators of migration growth in 2016 offset the natural reduction of urban population. Gradual decrease of urban population occurs in Ivanychi, Kivertsi and Rozhyshche districts. In Ki- vertsi district there are positive natural growth of urban population (as of early 2017), which inferior values of migration outflow, but in Ivanychi and Rozhyshche districts, one more reason of the reduction of urban residents number is negative value of natural growth.

In cities of regional subordination (except for Kovel) since 2016 there was a tendency to decrease the number of residents. The main reason for this is the migration outflow, and in Volodymyr-Volynskyi and Novovolynsk, there is also a natural decrease in the population (at the beginning of 2017, the natural growth rates in these cities were, $-2.3 \%$ and $-3 \%$, respectively). As for the other cities of Volyn region, the gradual increase in population during the studied time interval traced in Kamin-Kashyrskyi (by natural and migration processes), and in Liuboml (due to the predominance of positive values of negative migration growth indicators of natural population growth, marked by the beginning of 2017). The decrease in the urban population is observed in Kivertsi and Rozhyshche, which is primarily connected with the significant migration outflows, as well as negative values of natural growth, in particular in 2016.

Regarding the level of urbanization in the region, from the beginning of 2015 and before January 1,2017 , this figure remained unchanged, that is $52,3 \%$, while at the beginning of 2014 it was $52,2 \%$, and in $2013-52,1 \%$. Thus, the percentage of urbanization in Volyn region has stabilized. Currently, the number of urban population and the urbanization of Volyn region, in addition to natural reproduction of the population and intra-regional migration, have a significant impact on interregional and interstate migration flows. The stability of the urbanization index of Volyn region against the backdrop of reducing the urban population of some administrative districts and the number of inhabitants of most cities is due to a decrease in the number of rural residents of the region due to natural and migration processes.

Since urbanization reflects contemporary social and economic trends in the development of society, the issue of urban population settlements, its dynamics, and the spread of urban lifestyles remains among the most relevant research. Moreover, the same assessment and forecasting of the course of urbanization processes in Volyn region and other regions of Ukraine can become an important task on the way to increase the effectiveness of spatial planning, especially in the context of territorial and administrative reform.

\section{References}

1. Буряченко А. С. Урбанізація в контексті фінансового, демографічного та соиіального розвитку / А. Є. Буряченко // Вчені записки.: Збірник наукових працьь. - К.: КНЕУ, 2013. - Вип. 15. - С. 84-95. 
2. Венгрин Д. В. Типізація регіональних урбанізаційних прочесів в Україні / Д. В. Венгрин, К. Ю. Сегіда // Вісник Харківського національного університету імені В. Н. Каразіна, 2017. - Вип. 47. - С. 71-77.

3. Влах М. Р. Історико-географічні передумови формування системи розселення Волинської області / М. Р. Влах, В. І. Поручинський // Історія украӥнської географії. - Львів: [б. в.], 2007. - С. 32-39.

4. Галямар В. О. Урбанізачія: сутність та вплив на економічне зростання / В. О. Галямар // Вісник ЖДТУ, 2017. - Bun. 4 (82). - C. 72-76.

5. Дронова О. Л. Геоурбаністика: навч. посіб. / О. Л. Дронова. - К.: Видавничо-поліграфічний центр „Київський університет”, 2014. - 419 c.

6. Заставецький Т. Б. Система міських поселень агропромислового регіону в умовах трансформації суспільства: монографія / Т. Б. Заставецький. - Тернопіль, 2005. - 180 с.

7. Кихтюк В. Основні типи та кількість поселень на Волині / В. Кихтюк // Острозький краєзнавчий збірник. 2012. - Bun. 5. - C. 216-225.

8. Котенок Д. М. Економічна оцінка урбанізаційних процесів в Украӥні та формування економічного потенціалу міста / Д. М. Котенок // Інвестиції: практика та досвід. - 2013. - № 7. - C. 40-45.

9. Лажнік В. Просторовий аналіз особливостей розселення населення Волинської області з використанням центрографічного методу / В. Лажнік, С. Пугач // Часопис сочіально-економічної географії. - 2017. - Вип. 22. - C. 111-117.

10. Мельник М. І. Розвиток урбанізаиійних прочесів в умовах децентралізаиї: аналітична довідка / М. I. Мельник, С.Д. Щеглюк, Р. С. Яремчук // ДУ „Інститут регіональних досліджень ім. М. І. Долішнього НАН України”. - Львів, 2017. - 10 с.

11. Мольчак Я. О. Особливості геоекономічних та демографічних умов Волинської області / Я. О. Мольчак, I. В. Андрощук, І. Я. Мисковець // Економіка і суспільство: електронне наукове фахове видання. - Мукачево, 2017. - Bun. 10. - C. 503-509.

12. Олійник Я. Б. Урбанізація Волинської області: історичний аналіз та сучасні особливості з погляду життєдіяльності населення / Я. Б. Олійник, Г. С. Голуб // Географія та туризм. - 2012. - Вип. 18. - С. $214-221$.

13. Поручинський В. I. Активізація містоутворюючих функцій в умовах транскордонного співробітництва (на прикладі Волинської області) / В. І. Поручинський, М. Р. Влах // Науковий вісник Волинського національного університету імені Лесі Украӥнки. Географічні науки. - 2012. - № 18. - С. 76-80.

14. Прибиткова I. М. Еволючія міських систем у часі й просторі: украӥнський варіант розвитку / I. М. Прибиткова // Містобудування та територіальне планування. - 2011. - Вип. 41. - C. 351-368.

15. Прищепа О. П. Міста Волині у другій половині ХІХ - на початку XX ст.: монографія / О. П. Прищепа. Рівне: ПП ДМ, 2010. - 287 с.

16. Статистичний щзорічник. Волинь 2016 / за ред. В. Ю. Науменка. - Луцььк, ГУС у Вол. обл., 2017. - 450 с.

17. Стренгалюк А. В. Взаєморозвиток урбанізаційних та демографічних процесів в Украйні / А. В. Стренгалюк // Економічна та соціальна географія. - 2013. - Вип. 2. - С. 337-348.

18. Україна. Огляд прочесів урбанізаџї: звіт Світового Банку про урбанізацію України 1989-2013 рр., 2015. 216 c. [Електронний pecypc]. - Режим доступy: https://drive.google.com/file/d/ OB9jMMBcZIHvkdXE3XzlOc0JWem8/view

19. Чисельність наявного населення Украӥни на 01 січня 2013 р., 2016 р., 2017 р. [Електронний ресурс]. - Режим docmyny: http://database.ukrcensus.gov.ua

20. Beyond the metropolis: urban geography as if small cities mattered by Benjamin Ofori-Amoah, ed. Call Number: Baker/Berry GF 125. B49 2007. - 230 p.

21. Knox, Paul L. Urban social geography: an introduction / Paul Knox, Steven Pinch. - 6th ed. - 392 p.

22. Niemets L. Demographic situation as an indicator of socio-economic development (on example of Volyn and Kharkiv regions of Ukraine) / L. Niemets, M. Melniichuk, K. Segida, T. Pogrebskyi // Uniwersytet Ślaski Wydziat Nauk o Ziemi Sosnowiec 2016, Acta Geographica Silesiana, 22. WNoZ UŚ, Sosnowiec, 2016 - P. 43-57.

23. Niemets L. Regional settlement system as a factor of distribution of health care institutions (on example of Volyn region of Ukraine) / L. Niemets, K. Niemets, K. Segida, T. Pogrebskyi // Canadian Journal of Science, Education and Culture. - No.1. (5) (January-June). - Volume II. - Toronto: «Toronto Press», 2014. - P. 185-190.

24. The Future of Urban Sociology Tim May, Beth Perry, Patrick Le Galès, Saskia Sassen and Mike Savage - 2005. $343 p$.

25. The time of the city : politics, philosophy and genre by Michael J. Shapiro Call Number: Baker/Berry HT 151 .S454 2014. $-212 p$.

26. Urbanization : an introduction to urban geography by Paul L. Knox; Linda M. McCarthy Call Number: Baker/Berry GF 125 .K56 2005. - 564p.

Authors Contribution: All authors have contributed equally to this work. 
UDC 314.117.1(477.82)

\section{Tetiana Pavlovska,}

$\mathrm{PhD}$ (Geography), Associate Professor,

Department of Physical Geography, Faculty of Geography,

Lesya Ukrainka Eastern European National University,

9 Potapova Str., Lutsk, 43000, Ukraine,

e-mail: pavlovska2011@gmail.com, https://orcid.org/0000-0003-4931-0803,

Taras Pohrebskyi,

$\mathrm{PhD}$ (Geography), Associate Professor,

Department of Economic and Social Geography, Faculty of Geography,

Lesya Ukrainka Eastern European National University,

e-mail: taraspogrebskyi@gmail.com, https://orcid.org/0000-0002-2290-134X;

\section{Gennadii Golub,}

$\mathrm{PhD}$ (Geography), Associate Professor,

Department of Economic and Social Geography, Faculty of Geography,

Lesya Ukrainka Eastern European National University,

e-mail: golubgs111@gmail.com, https://orcid.org/0000-0003-3548-6998;

Volodymyr Poruchynsky,

$\mathrm{PhD}$ (Geography), Associate Professor,

Department of Economic and Social Geography, Faculty of Geography,

Lesya Ukrainka Eastern European National University,

e-mail: poruchynsky@ gmail.com, https://orcid.org/0000-0002-4605-5424

\section{URBAN POPULATION OF VOLYN REGION: RESETTLEMENT AND DYNAMICS}

Introduction. Currently, the spatial and temporal evolution of urban settlement systems has become an important object of the research at the regional, national and global levels. After all, urbanization is a rather complicated process. On the one hand, it is characterized by an increase in the size of the urban population, level of comfort and standard of living, modernization of all spheres of society's life. On the other hand, urbanization is accompanied by tensions regarding the use of basic natural resources, inconsistency in the demands of life comfort from the pace of development of housing and communal services and the planning structure of cities, etc. The study of the spatial and temporal evolution of the urban settlement systems is an important task on the regional, national and global levels. Therefore, the identification of resettlement patterns, the dynamics of urban processes and qualitative characteristics of the urban population, in particular, Volyn region are very relevant and deserve attention of modern geodemographers.

The aim of the article is to analyze the settlement of the existing urban population and its dynamics in Volyn region.

Research methodology. The following research methods are used: comparative-geographical, mathematical-statistical, method of geoinformation modeling (using MapInfo Professional 8.0 SCP).

The results of the research reflect the current urban tendencies in Volyn region, in particular, the unevenness of the settlement of the urban population through natural and economic factors. During the research period, the dynamics of the number of urban residents increased as a result of migration growth, and the percentage of urbanization in Volyn region stabilized. Currently, the number of urban population and the urbanization of Volyn region, in addition to natural reproduction of the population and intra-regional migration, have a significant impact on interregional and interstate migration flows. Since urbanization reflects contemporary socio-economic trends in the development of society, the issue of urban lifestyles remains among perspective research.

Scientific novelty and practical significance. The course, trends and dynamics of urbanization processes in Volyn and other Ukrainian regions have become an important task on the way to improving the effectiveness of spatial planning, especially in terms of territorial and administrative reform in Ukraine.

Keywords: Volyn region, migration growth, city, urban population, natural growth, urban-type settlement, urbanization.

\section{References}

1. Burjachenko, A. Je. (2013). Urbanizacija v konteksti finansovogho, demoghrafichnogho ta socialjnogho rozvytku [Urbanization in the context of financial, demographic and social development]. Vcheni zapysky - Scientists note, 15, 84-95 [in Ukrainian]. 
2. Venghryn, D. V., \& K. Ju. Seghida (2017). Typizacija reghionaljnykh urbanizacijnykh procesiv v Ukrajini [Unification of regional urbanization processes in Ukraine]. Visnyk Kharkivsjkogho nacionaljnogho universytetu imeni V. N. Karazina - The Journal of V. N. Karazin Kharkiv National University, 47, 71-77 [in Ukrainian].

3. Vlakh, M. R., \& Poruchynsjkyj, V. I. (2007). Istoryko-gheoghrafichni peredumovy formuvannja systemy rozselennja Volynsjkoji oblasti [Historical and geographical preconditions of the formation of the settlement system of Volyn region]. Istorija ukrajinsjkoji gheoghrafiji-History of Ukrainian Geography. (pp. 32-39). Ljviv [in Ukrainian].

4. Ghaljamar, V. O. (2017). Urbanizacija: sutnistj ta vplyv na ekonomichne zrostannja [Urbanization: the essence and the influence to economic growth]. Visnyk ZhDTU - Bulletin of Zhytomyr State Technological University, 4 (82), 72-76 [in Ukrainian].

5. Dronova, O. L. (2014). Gheourbanistyka [Urban geography]. Kyiv : Vydavnycho-polighrafichnyj centr ,,Kyjivsjkyj universytet" [in Ukrainian].

6. Zastavecjkyj, T. B. (2005). Systema misjkykh poselenj aghropromyslovogho reghionu v umovakh transformaciji suspiljstva: monoghrafija [The system of urban settlements in the agro-industrial region in the context of the transformation of society]. Ternopil [in Ukrainian].

7. Kykhtjuk, V. (2012). Osnovni typy ta kiljkistj poselenj na Volyni [The main types and the number of settlements in Volyn]. Ostrozjkyj krajeznavchyj zbirnyk - Ostrog regional collections, 5, 216-225 [in Ukrainian].

8. Kotenok, D. M. (2013). Ekonomichna ocinka urbanizacijnykh procesiv v Ukrajini ta formuvannja ekonomichnogho potencialu mista [Economic assessment of urbanization processes in Ukraine and formation of the economic potential of the city]. Investyciji: praktyka ta dosvid - Investments: practice and experience, 7, 40-45 [in Ukrainian].

9. Lazhnik, V., \& Pughach, S. (2017). Prostorovyj analiz osoblyvostej rozselennja naselennja Volynsjkoji oblasti z vykorystannjam centroghrafichnogho metodu [Spatial analysis of the population distribution of Volyn region using the centrographic method]. Chasopys socialjno-ekonomichnoji gheoghrafiji - Journal of Socio-Economic Geography, 22, 111-117 [in Ukrainian].

10. Meljnyk, M. I., \& Shheghljuk, S. D., \& Jaremchuk, R. Je. (2017). Rozvytok urbanizacijnykh procesiv v umovakh decentralizaciji : analitychna dovidka [Evolution of urbanization processes under decentralization: an analytical reference]. Lviv: DU „Instytut reghionaljnykh doslidzhenj im. M. I. Dolishnjogho NAN Ukrajiny” [in Ukrainian].

11. Moljchak, Ja. O., \& Androshhuk, I. V., \& Myskovecj, I. Ja. (2017). Osoblyvosti gheoekonomichnykh ta demoghrafichnykh umov Volynsjkoji oblasti [Features of geo-economic and demographic conditions of the Volyn region]. Ekonomika i suspiljstvo : elektronne naukove fakhove vydannja - Economics and Society: Electronic Scientific Specialty Edition, 10, 503-509 [in Ukrainian].

12. Olijnyk, Ja. B., \& Gholub, Gh. S. (2012). Urbanizacija Volynsjkoji oblasti: istorychnyj analiz ta suchasni osoblyvosti z poghljadu zhyttjedijaljnosti naselennja [Urbanization of the Volyn region: historical analysis and modern features according to the point of view of life of the population]. Gheoghrafija ta turyzm - Geography and tourism,18, 214-221 [in Ukrainian].

13. Poruchynsjkyj, V. I., \& Vlakh, M. R. (2012). Aktyvizacija mistoutvorjujuchykh funkcij v umovakh transkordonnogho spivrobitnyctva (na prykladi Volynsjkoji oblasti) [Activation of city-forming functions in conditions of cross-border cooperation (taking Volyn region as an example)]. Naukovyj visnyk Volynsjkogho nacionaljnogho universytetu imeni Lesi Ukrajinky - Scientific bulletin of Volyn National University named after Lesya Ukrainka, 18, 76-80 [in Ukrainian].

14. Prybytkova, I. M. (2011). Evoljucija misjkykh system u chasi j prostori: ukrajinsjkyj variant rozvytku [Evolution of urban systems in time and space: the Ukrainian version of development]. Mistobuduvannja ta terytorialjne planuvannja - Town planning and territorial planning, 41, 351-368 [in Ukrainian].

15. Pryshhepa, O. P. (2010). Mista Volyni u drughij polovyni KhIKh - na pochatku KhKh st. : monoghrafija [Volyn towns in the second half of the nineteenth and early twentieth centuries]. Rivne : PP DM [in Ukrainian].

16. Statystychnyj shhorichnyk. Volynj 2016 [Statistical Yearbook. Volyn 2016]. V. Ju. Naumenko (Eds). Lutsk, GhUS u Vol. obl. (2017) [in Ukrainian].

17. Strenghaljuk, A. V. (2013). Vzajemorozvytok urbanizacijnykh ta demoghrafichnykh procesiv v Ukrajini [Mutual development of urbanization and demographic processes in Ukraine]. Ekonomichna ta socialjna gheoghrafija Economic and social geograph, 2, 337-348 [in Ukrainian].

18. Ukrajina. Oghljad procesiv urbanizaciji: zvit Svitovogho Banku pro urbanizaciju Ukrajiny 1989-2013 rr. [Ukraine. Overview of the processes of urbanization: the World Bank report on the urbanization of Ukraine 1989-2013]. drive.google.com. Available at: http://drive.google.com/file/d/OB9jMMBcZIHvkdXE3XzlOc0JWem8/view [in Ukrainian].

19. Chyseljnistj najavnogho naselennja Ukrajiny na 01 sichnja 2013 r., 2016 r., 2017 r. [The number of the existing population of Ukraine on the first of January of 2013, 2016, 2017]. database.ukrcensus.gov.ua. Available at: http://database.ukrcensus.gov.ua. [in Ukrainian].

20. Beyond the metropolis: urban geography as if small cities mattered by Benjamin Ofori-Amoah, ed. (2007). Call Number: Baker/Berry GF 125.B49, 230.

21. Knox, Paul, Pinch, Steven (1982). Urban social geography : an introduction. 6th ed., 392.

22. Niemets L., Melniichuk M., Segida K., Pogrebskyi T. (2016). Demographic situation as an indicator of socioeconomic development (on example of Volyn and Kharkiv regions of Ukraine). Uniwersytet Ślaski Wydziat Nauk o Ziemi Sosnowiec 2016, Acta Geographica Silesiana, 22. WNoZ UŚ, Sosnowiec, 43-57. 
23. Niemets L., Niemets K., Segida K., Pogrebskyi T. (2014). Regional settlement system as a factor of distribution of health care institutions (on example of Volyn region of Ukraine). Canadian Journal of Science, Education and Culture. Toronto: «Toronto Press», 1(5) (January-June), II, 185-190.

24. Tim May, Beth Perry, Patrick Le Galès, Saskia Sassen and Mike Savage (2005). The Future of Urban Sociology. 343.

25. The time of the city : politics, philosophy and genre by Michael J. Shapiro (2014). Call Number: Baker/Berry HT 151.S454, 212.

26. Urbanization : an introduction to urban geography by Paul L. Knox; Linda M. McCarthy (2005). Call Number: Baker/Berry GF 125.K56, 564. 